Short Communication

\title{
High Prevalence Level of Avian Malaria in the Wild Population of the Java Sparrow
}

\author{
Tingginya Tingkat Prevalensi Malaria Burung pada Populasi Liar Gelatik Jawa
}

\section{Pramana Yuda}

Fakultas Teknobiologi Universitas Atma Jaya Yogyakarta, Jl. Babarsari 44 Yogyakarta 55281

E-mail: pramyd@mail.uajy.ac.id

Java sparrow (Padda oryzativa) is an endemic bird to Java and Bali. It used to be a very common bird, but due to over exploitation the bird has declined and been classified as Vulnerable (BirdLife International, 2001). In Indonesia bird-keeping is a popular pastime, with deep cultural roots (Jepson and Ladle, 2005). It is widely assumed that the hobby negatively affects wild populations of common as well as threatened birds (Jepson and Ladle, 2005; Nash, 1994), such as Java sparrow.

Other factors have been suggested as threats, i.e. destruction and habitat loss, intensive used of pesticide, and competition with Eurasian Tree sparrow (Balen, 1997; BirdLife International, 2001). So far, however, only the last factor has been studied systematically. These studies found that competition between Java sparrow with Eurasian Tree sparrow were not consistently present. Evidence from Sukawati (Bali), Sukabumi (West Java) and Malang (East Java) clearly suggests the occurrence of competition between the two species (Muchtar and Nurwatha, 2001), but not in Prambanan temples complex (Fanny et al., 2006) and Malang (pers. obs.) in which the two species were co-existing on the use of nest sites. Therefore further studies on these aspects are suggested to get more comprehensive understanding on the mechanism of the decline of the vulnerable Java sparrow.

Spread of virulent pathogen can have devastating demographic effects and significant impacts on the overall fitness of surviving individuals. For example, introduction of avian malaria and pox virus to Hawaiian Islands (Dobson and May, 1986). A study on blood parasite prevalence in forest bird in South-east Asia found that over $50 \%$ of the examined bird species were parasitized by more than one species (Paperna et al., 2005). However, little has been known about the level of the prevalence in non-forest bird in this area. This paper reports the finding of prevalence level of avian malaria in the wild population of Java sparrow using the molecular analysis.

\section{Sample}

In total, 38 DNA samples were used to assess the prevalence level of avian malaria in the Java sparrow. As comparison two common finches species, i.e. Chesnut Munia (Lonchura ferruginosa) and White-headed Munia (Lonchura maja), were also assessed, 15 samples respectively.

\section{Molecular Analysis}

A nested-PCR assay developed by Hellgren et al., (2004) was used which enable to detect in parallel three common genera blood parasites (Haemaproteus, Plasmodium, and Leucocytozoon) and involves two steps PCR. Firstly, to amplify the cytocrome b of these three genera. PCR included $\sim 50 \mathrm{ng}$ of total DNA, $1.25 \mathrm{mM}$ of each deoxynucleoside triphosphate, $1.5 \mathrm{mM} \mathrm{MgCl} 2,0.6 \mathrm{mM}$ of each primer, and 0.5 units Tag DNA polymerase. The primers used were HaemNFI (5'- CATA TATTAAGAGAAITATGGAG-3') and Haem NR3 (5'- ATAGAAAGATAAGAAATACC ATTC- -3 ').

The product of this PCR was used as template for the second PCR step, respectively $1 \mu \mathrm{l}$ for Haemoproteus spp.- Plamodium spp. and for Leucocytozoon spp. The primers used to amplify the former parasites were HaemF (5'-ATGGTGCTTTCGATATATGCATG - 3') and HaemR2 (5'- GCATTATCTGGATGTGA 
TAATGGT-3') (Bensch et al., 2000). Meanwhile the primers for the latter were HaemFL (5' - ATGGTGTTTTAGATACTTAC ATT - 3') and HaemR2L (5' - CATTATCTGG ATGAGATAATGGIGC - 3') (Hellgren et al., 2004). These PCR was run separately in $25 \mu \mathrm{l}$ with the same proportion of reagents as in the first PCR reactions. The thermal condition of the PCR was $94 \mathrm{C}$ for $30 \mathrm{sec}, 50 \mathrm{C}$ for $30 \mathrm{sec}$, and $72 \mathrm{C}$ for $45 \mathrm{sec}$. The samples were incubated before cyclic reaction at $94 \mathrm{C}$ for 3 min and after cyclic reaction at $72 \mathrm{C}$ for 10 min; 20 cycles for the first PCR and 30 cycles for the second one. To ensure consistency of the result 15 of the samples were run three times.

Final PCR products were visualized with electrophoresis, by loading $5 \mu$ of the products and $2 \mu \mathrm{l}$ of loading dye (Bromophenol Blue) onto a $2 \%$ agrose gel. Ethidium bromide $(\mathrm{EtBr})$ was included onto the gels to visualise the DNA. Gels were run in $x 1 \mathrm{TBE}$ buffer at 45 MA for approximately 25 minutes.

The PCR assay positively detected 11 out of 38 samples (28.95\%) for the Haemaproteus-Plasmodium parasites, but none for Lyucocytozoon in the Java sparrow blood. Meanwhile, both the blood parasites were not detected in either the Chesnut munia (Lonchura ferruginosa) nor in the White-headed munia (Lonchura maja). The repeatability test consistently produced the same results.

The positive samples then were selected for sequencing either using primer HaemF (for Haemoproteus spp.- Plamodium spp.). Double strand PCR products were purified by ethanol precipitation or spin column purification (Ultra Clean Tm, MO BIO Inc), prior to cycle sequenced using DYEnamic ET Dye Terminator Kit (MegaBACE). Sequencing products were purified and screened using MegaBACE ${ }^{\text {TM }}$ DNA Analysis Systems.
About 450 base pair region was consistently generated from all positive samples sequenced. Searching for similar sequences through NCBI's database (http:// www.ncbi.nlm.nih.gov/blast/) revealed that both Haemoproteus and Plasmodium infected the Java sparrow's blood. The prevalence of infection of the former parasite $(23.68 \%)$ was higher compared to those of the latter (5.26\%).

The sequences of Haemoproteus resulting from this study has $97-99 \%$ similarity with the published sequences of the same genus in the NCBI's database; and slightly smaller (9296\%) similarity for those of Plasmodium. These findings suggest new haplotypes of avian malaria specific to the Java sparrow, consisting of 3 haplotypes of Haemoproteus (h.1-3) and 2 haplotypes of Plasmodium (h.4-5) (Table 1).

This study found that the prevalence of avian malaria infection in the java sparrow was very high compare to those of the other two common indonesian finches species assayed in this study, and also higher compare to those of the forest bird in java (Paperna et al., 2005). Using blood smear method, the latter study found that among 27 bird species of 152 birds assayed the prevalence of infection were between $4.3-17 \%$ and $0-0.4 \%$, respectively for haemoproteus and plasmodiumrespectively, depending on the habitat types. Birds living in lowland forests of java seem to be more susceptible to infection (Paperna et al., 2005).

This finding suggests that the java sparrow was more prone to parasite infection, i.e. Avian malaria, compared to the more common finch species, but similar to other lowland forest birds in java. This factor could be another potential threat to bring to extinction of species. However, the impact of this infection to the demography of the Java sparrow is so far unknown. A control experiment may need to be set up to reveal this impact.

Table 1. Haplotypes of avian malaria found in the blood of the Java sparrow ( $h$ : haplotype; $n$ : number of samples).

\begin{tabular}{cccc}
\hline \hline h. & Sequence & n \\
\hline \hline 1 & CTCTTAACCTTTTCCACTTTATTTTAACATTTTTTCTTCCTTATGATACTCCCACTC & 5 \\
2 & CTTATAACTTCTTACACTTTATTTTAACATTTTCTATCCCTTATGATAATCTCATTT & 3 \\
3 & TTTTTTTTTATAAACTCATTATAATTCTGACTCTCAATTTAAGCATATTCATTATAT & 1 \\
4 & TCTTCTATTATTTTTATTACCATTCTCTGACATTCAATCTAAGCAAATTTTTTTTAT & 1 \\
\hline \hline
\end{tabular}




\section{Acknowledgments}

This study would not have been possibly without help and co-operation of local authorities and the assistance of many field assistants. In particular I wish to thank Ratna Indrawati, Sunaring Kurniandaru, Sapta Hutri, and Marsono. We gratefully acknowledge the financial assistance from Universitas Atma Jaya Yogyakarta (Indonesia), Lim Kok Seng Foundation (Singapore) and Australian Development Scholarship.

\section{References}

Balen, S.V. 1997. Java sparrow Padda oryzivora. PHPA/ BirdLife International Indonesia Programme, Bogor.

Bensch, S., Stjernman, M., Hasselquist, D., Ostman, O., Hansson, B., Westerdahl, H. and Torres Pinheiro, R. 2000. Host Specificity in Avian Blood Parasites: A Study of Plasmodium and Haemoproteus Mitochondrial DNA Amplified from Birds. Proceedings of the Royal Society Biological Sciences Series B 267: 1583-1589.

BirdLifeInternational. 2001. Threatened birds of Asia: the BirdLife International Red Data Book. BirdLife International, Cambridge, UK.

Dobson, A. and May, R. 1986. Disease and conservation In: Soule, M., (Eds). Conservation Biology: the Science of Scarcity and Diversity. Sinauer Associates, Inc., Sunderland, Massachusets.
Fanny, O., Yuda, P. and Jati, W.N. 2006. Nesting Niche Partition Between the Java Sparrow and Eurasian Tree-sparrow in the Pramabanan Temples Complex. J. of Ornithology. 147: 165

Hellgren, O., Waldenstrom, J. and Bensch, S. 2004. A New PCR Assay for Simultaneous Studies of Leucocytozoon, Plasmodium, and Haemoproteus from Avian Blood. J. of Parasitology 90: 797-802.

Jepson, P. and Ladle, R.J. 2005. Bird-keeping in Indonesia: Conservation Impacts and The Potential for Substitution-based Conservation Responses. Oryx 39: 442-448.

Muchtar, M. dan Nurwatha, P.F. 2001. Gelatik Jawa dan Jalak Putih: Status dan Upaya Konservasi di Jawa dan Bali (Java Sparrow and BlackWinged Starling: Status and Conservation Effort in Java and Bali). Yayasan Pribumi Alam Lestari, Bandung.

Nash, S.V. 1994. Sold for a Song - The Trade in Southeast Asian Non-CITES Birds. TRAFFIC International, Cambridge, UK.

Paperna, I., Soh, M.C.K., Yap, C.A.M., Sodhi, N.S., Lim, S.L.H., Prawiradilaga, D.M. and Nagata, H. 2005. Blood Parasite Prevalence and Abundance in The Bird Communities of Several Forested Locations in Southeast Asia. Ornithological Science 4. 